\title{
Biomass and waste incineration CHP: the co-benefits of primary energy savings, reduced emissions and costs
}

\author{
F. Levihn \& C. Nuur \\ Department of Industrial Economics and Management, \\ Royal Institute of Technology (KTH), Sweden
}

\begin{abstract}
Energy utility companies face trade-offs in navigating through today's environmental challenges. On the one hand they face intense political, social and environmental pressures to move towards adopting energy systems that incorporate the use of renewable energy resources. By making this transition they would contribute to carbon reduction and mitigate climate change. On the other hand, they need to coordinate their resources and become efficient when investing in new plants or upgrading existing production systems. This paper seeks to address the gains that utility companies can make when replacing older fossil fuel base- plants with efficient combined heat and power (CHP) plants. We discuss the system effects from the changes in production of other units when new plants are constructed. Using one of the largest energy utility companies in Sweden, Fortum, as an empirical point of departure, we analyzed the company's transition from using coal and hydrocarbons to an increased use of renewables and waste incineration CHP. Our analysis was based on comprehensive production data on $\mathrm{CO}_{2}, \mathrm{SO}_{\mathrm{x}}$ and $\mathrm{NO}_{\mathrm{x}}$ emissions. Our findings suggest that primary energy consumption drops when older and less efficient fossil plants are substituted for new efficient CHP plants; this drop includes the effect on the remaining production. The benefits in terms of primary energy savings might be even greater than what are achieved in meeting the goal of climate change abatement through reduced $\mathrm{CO}_{2}$ emissions; $\mathrm{NO}_{\mathrm{x}}$ and $\mathrm{SO}_{\mathrm{x}}$ emissions are decreased with new biomass CHPs. Waste incineration CHP increase $\mathrm{NO}_{\mathrm{x}}$ and $\mathrm{SO}_{\mathrm{x}}$ emissions, when there is less fossil fuel to replace after the use of biomass is extended. In both cases, economic efficiency increases as costs are reduced.

Keywords: district heating, environmental impact, primary energy consumption.
\end{abstract}




\section{Introduction}

The expansion of biomass and waste incineration combined heat and power (CHP) production within district heating (DH) systems is generally regarded as environmentally friendly. However, it is not free from emissions. In particular, the sulfur oxides $\left(\mathrm{SO}_{\mathrm{x}}\right)$ and nitrous oxides $\left(\mathrm{NO}_{\mathrm{x}}\right)$ emissions make the greatest impact on the local environment [1].

The political and academic discussions on climate change have put the impact of $\mathrm{NO}_{\mathrm{x}}$ and $\mathrm{SO}_{\mathrm{x}}$ on the local environment in the shadow of the impact of carbon dioxide $\left(\mathrm{CO}_{2}\right)$ emissions [2]. This was also evident by the investment patterns of utility companies, where it has been shown that costs followed by $\mathrm{CO}_{2}$ emissions are the major evaluation criteria [3]. At the same time, air quality issues are aggregated by many green initiatives which focus on $\mathrm{CO}_{2}$ reductions, which is why air quality implications need to be addressed [4]. Drawbacks in terms of air pollution have, for example, been claimed for biofuels relative to their fossil counterparts [2].

Energy systems are complex and interconnected and the introduction of new technologies or the construction of new plants have an effect on the existing production. In the case of waste incineration in France, it has been shown that $25 \%$ of present plants contribute to reducing air pollution and less than $2 \%$ to reducing climate-change-related emissions [5]. In the carbon capture and storage (CCS) technology, if the technology was added to an existing production system a small impact on air pollution were found, but a greater reduction would be obtained if CCS were combined with the integrated gasification combined cycle (IGCC) technology [6]. According to this study, the importance is which type of production is replaced and that climate change abatement and reduction of air pollution most often go hand in hand for the CCS related technologies. It has also been claimed that a $15 \%$ reduction in $\mathrm{CO}_{2}$ emissions from the EU15 would have positive spillover effects on sulfur dioxide $\left(\mathrm{SO}_{2}\right)$ and $\mathrm{NO}_{\mathrm{x}}$ emissions, which would be reduced $25 \%$ and $8 \%$, respectively [2].

Energy utility companies face trade-offs in navigating today's environmental challenges. There are profound political, social and environmental pressures on them to move toward adopting energy systems that incorporate the use of renewable energy resources.

This paper seeks to address the gains utility companies can make when they substitute efficient CHP plants for older fossil fuel-based plants. We discuss the system effects from the changed production of other units when new plants are constructed and the primary energy (PE) savings that could be attained. Using one of the largest energy utility companies in Sweden, Fortum, as an empirical point of departure, we analyzed its transition from coal and hydrocarbons to an increased use of renewables and waste incineration CHPs. Our analysis was based on comprehensive operational data on $\mathrm{CO}_{2}, \mathrm{SO}_{\mathrm{x}}$ and $\mathrm{NO}_{\mathrm{x}}$ emissions that we obtained in collaboration with the firm. The main contribution of this study is to show the effect of an increased application of biomass and waste incineration CHP in a district heating system with a mix of fossil and renewable production 
by posing the following question: What are the effects of a new bio-mass-based CHP unit and a new waste incineration CHP within a DH system, as regards PE consumption, $\mathrm{CO}_{2}, \mathrm{SO}_{\mathrm{x}}$ and $\mathrm{NO}_{\mathrm{x}}$ emissions, respectively?

\section{The south/central Stockholm district heating system}

Stockholm has two large DH networks. In an average year, the south/central Stockholm DH system produces about 9.7 TWh of heat and 1.7 TWh of electric power. The system consists of many production units that use different kinds of technologies and fuel. The base load production is mainly based on CHP from waste incineration, biomass and coal. Middle load production is based on a combination of CHP, electric heat pumps (HP) and heat only boilers (HOB). The middle load uses a combination of biomass, waste incineration and electricity as fuel. Peak load is mainly based on fossil and bio oil. Even though the fossil oil equals $1500 \mathrm{MW}$ in installed capacity, it is only responsible for the production of $0.08 \mathrm{TWh}$ annually.

The main actor of the Stockholm DH systems is AB Fortum Värme samägt med Stockholms stad (Fortum Värme), a utility firm which has a market share of $80 \%$ of heat delivered within the region. It is a subsidiary owned jointly with the Municipality of Stockholm and the Finish-based multinational utility Fortum group. Fortum Värme is a multi-utility firm that in addition to providing DH provides district cooling, waste disposal through waste incineration, electric power production and energy services. Peak production is dispersed around the Stockholm region and the major plants of the south/central network analyzed in this study are as follows):

- Hammarbyverket, which was constructed in 1986, has one of the largest HP capacities in the world. This production plant is an integrated part of the highly profiled "green" area of Hammarby Sjöstad, which has been marketed as the "residential area" of the future and has bio oil and electric HOBs installed.

- Värtaverket is one of the largest production systems for district heating and cooling in Europe. The plant is located close to the end users and in the northeast of the city, and has a seaport. To reduce the use of coal and oil and increase the share of renewables within production, a large scale biomass CHP unit called KVV8 is under construction at Värtaverket.

- Högdalenverket is located in the southern suburbs and is mainly based on waste incineration CHP, although bio oil HOBs are available for peak production. There are plans to construct a large waste incineration CHP plant to be ready by 2015 , thereby, expanding the capacity for waste management within the region.

\section{Methodology}

The calculations in this study were conducted with the aid of Optima, investment optimization software. Many different software programs might be used in this type of studies (e.g., MARKAL, MARTES, HEATSPOT). However, for our 
purposes Optima was the ideal software because Fortum Värme uses it and granted access to the software and different technical parameters. Data was adopted for the present production in the south/central Stockholm DH system, together with data on future investment.

\subsection{Optima}

The system analyzed is described using an annual load duration curve based on the empirical details of production in the system. Thus, Optima is similar to the HEATSPOT/EUROPSOT model (see, e.g., [7-9]). Variable operational costs together with technical parameters were used to establish merit order and an energy balance. The technical parameters were based on actual production data.

All variable costs were allocated to heat generation, with revenue from power sales and policy incentive mechanisms added where applicable. Fixed costs were handled separately and did not affect the energy balance or merit order. While this might be inappropriate for free-market systems, it is suitable for optimizing a monopoly, such as a DH system in which one firm bears all costs.

\subsection{Source of calculation and allocation methods}

The technical data used for calculations was based on actual operational data. To ensure reliability of the calculations, the results were compared to environmental reports regarding Värtaverket [10] and Högdalen [11]. PE consumption was calculated according to the Swedish Heat Market Committee [12], which defines the accounting principles to be used within the sector. It is worth noting this means that calculations of PE were made according to the standard accounting principles of the DH industry in Sweden.

All costs are presented in Swedish crowns (SEK). At the time of writing, EUR 1 was approximately SEK 9. MSEK represents millions of SEK. $\mathrm{SO}_{\mathrm{x}}$ and $\mathrm{NO}_{\mathrm{x}}$ emissions are discussed as metric tonnes $(\mathrm{t}), \mathrm{CO}_{2}$ emissions in thousand metric tonnes or kilotonnes $(\mathrm{kt})$. The emissions were calculated for the whole network including production from other actors in addition to Fortum Värme; these are presented as "other" in the tables. PE consumption was calculated only in relation to Fortum Värme's production.

\section{Results and discussion}

\subsection{Värtaverket}

Värtaverket is a large multi-utility production site. Constructed in 1903 outside the Stockholm city borders, the plant was originally constructed for producing electricity from coke and oil. It was expanded during the 1960s and 1970s with the introduction of large oil-fired CHP unit with two fossil oil HOBs. As Stockholm grew, Värtaverket found itself inside the city borders. By then, it was one of the largest thermal plants with electric boilers in the world. During the 1980s, HPs that used the thermal energy in seawater were installed; they had the 
potential of supplying central Stockholm with DH from spring to early autumn. Today, Värtaverket has the largest installed HP capacity in the world.

Considerations for the local environment were of great importance in the 1970s when the operator of Värtaverket was choosing technologies for its future production. At this time, however, greenhouse gas emissions were in practice not considered an issue. For a new unit called KVV6, the pressurized fluidized bed combustion (PFBC), which is a clean coal technology [13]. PFBC made it possible to remove $95-99 \%$ of the $\mathrm{SO}_{\mathrm{x}}$ and $\mathrm{NO}_{\mathrm{x}}$ formed. Additional gas cleaning technologies enabled the removal of most of the particulate emissions and radioactive isotopes. The operation of the carbon stocks was one of the most important factors considered when the new plant was designed. Previous operations at the seaport, as well as open stockpiles, had affected the local environment negatively for decades. The solution was a closed automated fuel handling system from the seaport to two P-200 PFBC boilers. This prevented the spreading of dust in the harbor surrounding areas. An underground storage facility was built in the cavern under the plant, where it is possible to store 100,000 metric tonnes of carbon (half the annual consumption). From there, the coal is transported to a preparation facility where it is crushed and mixed with dolomite, limestone and water. The carbon paste is then used in the PFBC boilers. Today the combined production from Värtaverket is $3.3 \mathrm{TWh}$ heat, 0.9 TWh electricity and $0.3 \mathrm{TWh}$ district cooling.

The increased focus on climate change has resulted in a less positive view of coal power compared to that when KVV6 was constructed. To sustain competitiveness and to take into account local opinions, Fortum Värme took measures to reduce $\mathrm{CO}_{2}$ emissions and the use of coal and other fossil fuels. One such measure is the installation of a new biomass fluidized bed combustion (FBC) unit called KVV8. While the PFBC technology is arguably well suited for the local environment, $\mathrm{FBC}$ technology is in some ways less so. Compared to FBC, PFBC is compact to start with. To comply with local building regulations, the new plant is currently being built in a pit to reduce the overall height of the plant. Further, a closed fuel handling system, similar to the system now used for KVV6 is under construction to reduce the impact of handling fuel on the local environment. An underground oil silo is available and could be transformed for storing biomass together with the existing $144 \mathrm{~m}$ chimney.

The economics of the investment are affected by different environmental legislation. Electricity prices are high enough to support the investment in CHP production. The taxes on fossil fuels and $\mathrm{CO}_{2}$ emissions reduce the competitiveness of these resources. The DH production is also included within the trading sector of the European Union emissions trading scheme (EU ETS). Further, there are economic incentives for renewable electricity production through the Swedish green certificate system.

As KVV8 is introduced, it will affect the use of other production units. Some methods of production such as waste incineration will be less affected because fuel costs are negative. Other production units will be used less. Among these are KVV6, the HPs and other biomass CHPs and the HOBs. The effect is spread through the region. 
Table 1: The effect on emissions and PE consumption from building the waste biomass FBC CHP plant KVV8 at Värtaverket.

\begin{tabular}{|l|c|c|c|c|c|}
\hline & {$[t]$} & {$[t]$} & & {$[k t]$} & {$[T W h]$} \\
\hline & $\mathbf{N O}_{\mathbf{x}}$ & $\mathbf{S O}_{\mathbf{x}}$ & & $\mathbf{C O}_{\mathbf{2}}$ & $\mathbf{P E}$ \\
\hline Värtan & 178 & 32 & & & \\
\hline Hammarby & -58 & -5 & & & \\
\hline Högdalen & 0 & 0 & & & \\
\hline Peak Production & -31 & -16 & & & \\
\hline Other & -116 & -12 & & & \\
\hline Total & -27 & -1 & & -158 & -1.02 \\
& $-2.0 \%$ & $0.6 \%$ & & $-13.5 \%$ & $-20.6 \%$ \\
\hline
\end{tabular}

\subsection{1 $\mathrm{CO}_{2}$ and primary energy consumption}

The combined effect of reduced production from the other units results in a net reduction of $158 \mathrm{kt} \mathrm{CO}_{2}$ annually. This corresponds to a $13.5 \%$ reduction of the total $\mathrm{CO}_{2}$ emissions resulting from the production of $\mathrm{DH}$ in Stockholm. The decrease is attributed to a reduced use of other production units, including the KVV6 and fossil oil HOBs. While one of the main goals is the reduction of $\mathrm{CO}_{2}$, the $\mathrm{PE}$ consumption is in fact reduced more than $1 \mathrm{TWh}$, which corresponds to $20.6 \%$. This decrease is attributed to the reduced use of other production units, including the HPs which do not contribute directly to $\mathrm{CO}_{2}$ emissions.

Building KVV8 will also increase the production capacity and export of electric power from the south/central Stockholm DH system to the Nordic electricity network. The combined effect of an increased share of CHP to HOB production and decreased HP production, will increase the net electric power export from the DH system $0.64 \mathrm{TWh}$ annually. This corresponds to an additional replacement of 1.24 TWh of PE used for the alternative electric power production.

\subsubsection{Effect on $\mathrm{NO}_{\mathrm{x}}$ and $\mathrm{SO}_{\mathrm{x}}$ emissions}

The reallocation of emission sources within the region from the suburbs to production close to the city center has an effect on $\mathrm{NO}_{\mathrm{x}}$ and $\mathrm{SO}_{\mathrm{x}}$ emissions. According to our calculations, the combined effect of the reduced production from KVV6 and new production from KVV8 increase $\mathrm{NO}_{\mathrm{x}}$ emissions by $178 \mathrm{t}$ annually at Värtaverket. However, because less $\mathrm{NO}_{\mathrm{x}}$ is emitted elsewhere there is a net reduction of $27 \mathrm{t}$ for the whole region. $\mathrm{SO}_{\mathrm{x}}$ emissions were affected less in absolute numbers, and the total increase in SOx emissions is about the same as the decrease from other production. The chimney that is used for KVV6 and will be for the KVV8 is $144 \mathrm{~m}$ high and favorable wind conditions on average from southwest result in the highest concentrations dispersed at less densely populated areas or the sea [14]. Production at Hammarbyverket is less favored by the prevailing wind conditions, which is why a reduction in $\mathrm{NO}_{\mathrm{x}}$ and $\mathrm{SO}_{\mathrm{x}}$ has positive effects on the local environment for the southern part of the city. 


\subsection{Högdalenverket}

In the 1960s, a general policy called "den Svenska linjen" (the Swedish line) was adopted. This called for an expansion of nuclear power and a development of nuclear weapons, independent of foreign countries. Between 1963 and1974, the first Swedish commercial nuclear reactor operated in the south of Stockholm (Ågesta) to produce electricity and to supply the southern suburbs with district heating.

In the 1960s, as the population grew, the need for waste disposal became urgent in the Stockholm region. In 1963, a decision was made to build a waste incineration plant in Högdalen and in the early 1970s two boilers became operational with a capacity to incinerate $15 \mathrm{t}$ of household waste per hour. The plant was first connected to the DH network in 1979 during construction of the new waste incineration CHP and peak production HOBs.

The expansion and incremental development of the plant continued and in 1999 a FBC unit was added to burn industrial waste (PTP). In 2004, the latest waste incineration CHP unit was built, and today the plant incinerates around $700,000 \mathrm{t}$ of household waste annually. To reduce the impact on the local environment, flue gas cleaning takes place in multiple steps consisting of electrical filtering, wet scrubbing, venturi and flue gas condensation. In total, the plant produces 3.6 TWh heat, 0.3 TWh electricity and $0.1 \mathrm{TWh}$ of district cooling annually.

Currently, there are plans to expand Högdalen and add an additional waste incineration CHP unit called KVV7 or P7, which is scheduled to be operational in 2015. This unit is expected to add 0.6 TWh heat and $0.2 \mathrm{TWh}$ electricity annually. The fuel cost for waste is negative because utilities with incinerators are paid for burning the waste. This places waste incineration plants high in merit order.

Table 2: The effect on emissions and PE consumption from constructing the waste incineration CHP plant KVV7.

\begin{tabular}{|l|c|c|l|c|c|}
\hline & {$[t]$} & {$[t]$} & & {$[k t]$} & {$[T W h]$} \\
\hline & $\mathbf{N O}_{\mathbf{x}}$ & $\mathbf{S O}_{\mathbf{x}}$ & & $\mathbf{C O}_{\mathbf{2}}$ & $\mathbf{P E}$ \\
\hline Värtan & -11 & -2 & & & \\
\hline Hammarby & -13 & -1 & & & \\
\hline Högdalen & 77 & 13 & & & \\
\hline Peak Production & -6 & -3 & & & \\
\hline Other & -46 & -5 & & & \\
\hline Total & 1 & 2 & & 7 & -0.34 \\
& $0.1 \%$ & $1.2 \%$ & & $0.6 \%$ & $-8.7 \%$ \\
\hline
\end{tabular}

\subsection{1 $\mathrm{CO}_{2}$ and primary energy consumption}

The construction of KVV7 will result in a slight increase in the $\mathrm{CO}_{2}$ emissions resulting from production within the south/central Stockholm DH system. However, if KVV8 were not built, there would be a small decrease in $\mathrm{CO}_{2}$ 
emissions. This would result from the reduction in coal- and oil-based production as the amount of biomass-based production increased. When it comes to $\mathrm{PE}, \mathrm{KVV} 7$ results in a $0.34 \mathrm{TWh}$ reduction in $\mathrm{PE}$ consumption, which is equal to a further reduction of $-8.7 \%$.

\subsubsection{Effect on $\mathrm{NO}_{\mathrm{x}}$ and $\mathrm{SO}_{\mathrm{x}}$ emissions}

When KVV8 starts production, its $\mathrm{SO}_{\mathrm{x}}$ and $\mathrm{NO}_{\mathrm{x}}$ emissions will be transferred to less densely populated areas. With KVV7 the effect is the opposite. Even if Högdalenverket were situated in a less populated area compared to Värtaverket and KVV8, the emissions from its chimney would affect an area that is more populated than the area affected by KVV8. While the $\mathrm{NO}_{\mathrm{x}}$ emissions will be increased locally by building KVV7, the increase is about the same as the decrease elsewhere in the region. There will be an increase in $\mathrm{SO}_{\mathrm{x}}$ emissions at Högdalen, countered to some extent by reductions from the rest of the region, resulting in an overall increase of $1.2 \%$.

\subsection{Combined effect}

While there are pros and cons with investing in new production, the combined effect of investing in KVV8 and KVV7 needs to be considered.

Table 3: The combined effect of the combined constructing the biofuel CHP plant KVV8 and the waste incineration CHP plant KVV7.

\begin{tabular}{|l|c|c|c|c|c|}
\hline & {$[t]$} & {$[t]$} & & {$[k t]$} & {$[G W h]$} \\
\hline & $\mathbf{N O}_{\mathbf{x}}$ & $\mathbf{S O}_{\mathbf{x}}$ & & $\mathbf{C O}_{\mathbf{2}}$ & $\mathbf{P E}$ \\
\hline Värtan & 167 & 30 & & & \\
\hline Hammarby & -71 & -6 & & & \\
\hline Högdalen & 77 & 13 & & & \\
\hline Peak Production & -37 & -19 & & & \\
\hline Other & -162 & -17 & & & \\
\hline Total & -26 & 1 & & -151 & -1361 \\
& $-1.9 \%$ & $0.6 \%$ & & $-11.4 \%$ & $-27.5 \%$ \\
\hline
\end{tabular}

\subsection{1 $\mathrm{CO}_{2}$ and primary energy consumption}

The increased proportion of biofuel and waste incineration CHPs compared to HOBs and coal- and oil-based production has had a positive impact on both climate change abatement and reduction in PE consumption. KVV8 will have a significant impact on climate change abatement in reducing the $\mathrm{CO}_{2}$ emissions resulting from DH production within the Stockholm region by $13.5 \%$. When KVV8 is constructed though, there will be less fossil production for KVV7 to replace. In the end, about the same amount of $\mathrm{CO}_{2}$ will be replaced as would be introduced if KVV7 is constructed. The combined effect is an $11.4 \%$ reduction.

KVV8 replaces as much oil- and coal-based production so, when and if, KVV7 is constructed, there will be less to replace, which is why there would be a small increase in $\mathrm{CO}_{2}$ emissions. If KVV7 is constructed before KVV8, it would 
reduce $\mathrm{CO}_{2}$ emissions, but then the reductions from KVV8 would be smaller, a result that is similar to [5]. From a PE consumption perspective, both units have a positive effect. According to our calculations, the two units combined would reduce $\mathrm{PE}$ by $1.36 \mathrm{TWh}$ annually, which is a significant $27.5 \%$ reduction compared to the present PE consumption by Fortum Värme.

\subsubsection{Effect on $\mathrm{NO}_{\mathrm{x}}$ and $\mathrm{SO}_{\mathrm{x}}$ emissions}

While KVV8 reduces overall $\mathrm{NO}_{\mathrm{x}}$ emissions, KVV7 reduces $\mathrm{SO}_{\mathrm{x}}$. In both cases, the emissions from Hammarbyverket are projected to decline, which will improve air quality for the southern part of Stockholm. The combined effect is a $1.9 \%$ reduction of $\mathrm{NO}_{\mathrm{x}}$ spread across the region. The largest local increase is at Värtaverket; even though this plant is centrally located, wind conditions combined with the $144 \mathrm{~m}$ chimney disperse the emissions to less populated areas. For the whole region, $\mathrm{NO}_{\mathrm{x}}$ is reduced by $26 \mathrm{t}$ annually which corresponds to $1.9 \%$. $\mathrm{SO}_{\mathrm{X}}$ emissions on the other hand are increased by $1 \mathrm{t}$, corresponding to a $0.6 \%$ increase for the whole region.

\subsection{Enabling capabilities and context}

\subsubsection{Economic}

Constructing KVV8 and KVV7 is financially sound and will reduce production costs because of a number of factors. Starting with their capabilities, the production that will be replaced is, in both cases, more expensive. There must also be sufficient heat load for the higher fixed cost of CHP to be competitive relative the HOBs. The competitiveness is in turn a result of many contextual factors. Among them is the combined effect of fuel prices of alternative production and economic policy such as $\mathrm{NO}_{\mathrm{x}}$ and electricity taxes, EU ETS and green certificates (favoring renewable electricity production). These affect both the future operation of KVV8 and KVV7 and the savings made when other production is operated at a slower rate. Thus the path dependent aspects of previous measures taken are highly relevant [15-16].

Another enabling capability that strongly contributes to the operational costs of the two plants is the current infrastructure. Both units will be built at existing production sites. As a result, the costs are lower compared to what they would have been if the enabling infrastructure also needed to be constructed. Another important capability that will contribute to reduced costs is experience with handling the automated fuel handling process for KVV6; it will be valuable because a similar system is being implemented for KVV8.

\subsection{2 $\mathrm{CO}_{2}$}

The financial performance of the two plants puts them high in merit order because the use of the coal and oil-based production capacity will be reduced. If they were too low in merit order, they would be replaced by oil and/or coal and the performance, from a $\mathrm{CO}_{2}$ perspective, would be reduced. In other words, the relative operating cost is one of the key capabilities that determine the basis on which alternative production will be replaced. 
Beylot and Villeneuve [5] discussed the importance of the fossil share of replaced production; it is also possible to further identify which circumstances define how much fossil production is replaced. Not only is the present production mix important, but how this translates into financial performance of the new production is also important. A performance that in turn is both dependent on internal capabilities as well as the external context.

\subsubsection{Primary energy consumption}

Climate change mitigation is strongly dependent on which alternative production that is replaced, but, in our case, PE consumption is even more strongly dependent on it. The financial performance of the new production unit and thus what alternative production would be replaced is most important. Production with a higher PE intensity such as coal- and oil-based production will be reduced by both KVV8 and KVV7. Additionally, the reduced use of electricity for heat production in the HPs and electric HOBs will further decrease PE consumption.

As the share of CHP increases in comparison to that of the HOBs, electricity production increases. There would be double effects because the amount of electricity consumed by electric HPs and HOBs would be reduced. This would vastly increase the impact of the new CHP in the south/central Stockholm DH network in terms of net electricity exported to the Nordic power grid. The resulting additional $0.8 \mathrm{TWh}$ is significant. If the PE consumption of replaced Nordic electricity production is taken into account, the marginal PE saving are more than doubled. This would be significantly reduced if the new plants were to rank behind the HPs in merit order.

\subsection{4 $\mathrm{NO}_{\mathrm{x}}$ and $\mathrm{SO}_{\mathrm{x}}$}

Both $\mathrm{NO}_{\mathrm{x}}$ and $\mathrm{SO}_{\mathrm{x}}$ emissions are dependent on which type of production is replaced. Thus, one key capability is the economic performance of the new production plant. For KVV8, the height of the present chimney is another advantage, which together with favorable wind conditions allow less pollution to affect densely populated areas. Another advantage is the reduced production from Hammarbyverket, which has a positive effect on the local environment of the southern parts of inner city in Stockholm. Given the present structure of the south/central DH-system in Stockholm, the effect on $\mathrm{SO}_{\mathrm{X}}$ and $\mathrm{NO}_{\mathrm{x}}$ emissions is rather small, why the geographical change to affected areas is of greater importance.

\section{Conclusion}

The impact of waste incineration and biomass CHP plants is strongly connected to existing production, which provides strong path dependency based on previous decisions and investments. The effect is also dependent on which existing production plant is replaced. In this paper, we have shown that the competitiveness of a new production plant is essential for what and how much of the present production is replaced when building new plants. This is based on a combination of enabling capabilities and the context of the two technologies. 
If waste incineration and biomass CHP plants are able to replace coal and oilbased production, benefits in terms of reduced $\mathrm{PE}$ consumption and reduced $\mathrm{CO}_{2}$ emissions would be realized. $\mathrm{NO}_{\mathrm{x}}$ and $\mathrm{SO}_{\mathrm{x}}$ emission levels are heavily dependent on which production is replaced. In the example of the Stockholm south/central $\mathrm{DH}$ network, the new biomass CHP plant KVV8 would reduce $\mathrm{NO}_{\mathrm{x}}$ emissions, but have a small impact on $\mathrm{SO}_{\mathrm{x}}$. For the new waste incineration CHP unit KVV7, $\mathrm{NO}_{\mathrm{x}}$ would only marginally be affected and $\mathrm{SO}_{\mathrm{x}}$ would slightly increase. When the impact of both plants are combined, $\mathrm{NO}_{\mathrm{x}}$ emissions are reduced within the system, but SOx emissions will be about about the same as before. As the source of the emissions is transferred within the region, there could be benefits because the prevailing wind conditions would allow air quality to improve in the southern part of the city. As the change to $\mathrm{SO}_{\mathrm{x}}$ and $\mathrm{NO}_{\mathrm{x}}$ emissions is rather small, it is instead more important to understand what areas, in relation to other production within the system, will be affected when biomass and waste incineration CHP production is expanded.

The construction of KVV8 reduces the amount of fossil-based production that KVV7 could replace, because KVV7 would slightly increase $\mathrm{CO}_{2}$ emissions by $0.6 \%$. In total, the combined effect of the plants is an $11.4 \%$ reduction of $\mathrm{CO}_{2}$, a $27.5 \%$ reduction of $\mathrm{PE}$ consumption, a $6.6 \%$ reduction of $\mathrm{SO}_{\mathrm{x}}$ emissions and a $1.9 \%$ reduction of $\mathrm{NO}_{\mathrm{x}}$ emissions.

\section{Acknowledgements}

This study was financed by the Swedish Energy Agency under the program "Investments in energy efficiency and climate change abatement: revising marginal cost curves as an optimization model." It was executed in cooperation with the district heating utility AB Fortum Värme samägt med Stockholms Stad.

\section{References}

[1] Fahlen E. \& Ahlgren, E.O., Accounting for external costs in a study of a Swedish district-heating system - An assessment of environmental policies, Energy Policy, 38, pp. 4909-4920, 2010.

[2] Sliggers, J., The need for more integrated policy for air quality, acidification and climate change: reactive nitrogen links them all, Environmental Science \& Policy, 7, pp. 47-68. 2004.

[3] Wang, J., Jing, Y., Zhang, C. \& Zhao, J., Review on multi criteria decision analysis in sustainable energy decision-making, Renewable and Sustainable Energy Reviews, 13, pp. 2263-2278, 2009.

[4] Tiwary, A., Namdeo, A., Fuentes, J., Dore, A., Hu, Z. \& Bell, M., Systems scale assessment of the sustainability implications of emerging green initiatives, Environmental Pollution, 182, pp. 213-223. 2013.

[5] Beylot, A. \& Villeneuve, J., Environmental impacts of residual Municipal Solid Waste incineration, A comparison of 110 French incinerators using a life cycle approach, Waste Management, 33, pp. 2781-2788, 2013. 
[6] Koornneel, J., Ramirez, A., van Harmelen, T., van Horssen, A., Turkenburg, W. \& Faaij, A., The impact of CO2 capture in the power and heat sector on the emissions of $\mathrm{SO} 2, \mathrm{NOx}$, particulate matter, volatile organic compounds and NH3 in the European Union, Atmospheric Environment, 44, pp. 1369-1385, 2010.

[7] Egeskog, A., Hansson, J., Berndes, G., \& Werner, S., Co-generation of biofuels for transportation and heat for district heating systems: an assessment of the nation possibilities in EU, Energy Policy, 37, pp. 5260-5272, 2009.

[8] Knutsson, D., Sahlin, J., Werner, S., Ekvall, T. \& Ahlgren, E.O., HEATSPOT: a simulation tool for national district heating analysis, Energy, 31, pp. 278-293, 2006.

[9] Knutsson, D., Werner, S. \& Ahlgren, E.O., Combined heat and power in the Swedish district heating sector: impacts of green certificates and CO2 trading on new investments, Energy Policy, 34, pp. 3942-3952, 2006.

[10] Nordin, O., Miljörapport för Värtaverket 2011, AB Fortum Värme samägt med Stockholm stad: Stockholm, 2012.

[11] Åkerlund, N., Miljörapport för Högdalenverket 2011 version 1, AB Fortum Värme samägt med Stockholm stad: Stockholm, 2012.

[12] VMK, Överenskommelse i Värmemarknadskomittén 2012: om synen på bokförda miljövärden för fastigheter uppvärmda med fjärrvärme. Justerad i januari 2013 med värden för 2012, Värmemarknadskomittén, ISBN 97891-85775-14-9, 2013.

[13] Franco, A. \& Diaz, A.R., 2006. "The future challenges for 'clean coal technologies': Joining efficiency increase and pollutant emission control", Energy, 34, pp. 348-354, 2006.

[14] SLB, Förändrad och utökad verksamhet vid Värtverket år 2010: spridningsberäkningar av halter inandningsbara partiklar (PM10), käveoxid (NO2), Svaveloxid (SO2) och väteklorid (HCL) samt deposition. Stockholms och Uppsala läns luftvårdsförbund, report 2006:3, February, 2006.

[15] Criqui P., Mima S. \& Viguier L., Marginal abatement cost of $\mathrm{CO} 2$ emission reductions, geographical flexibility and concrete ceilings: an assessment using the POLES model, Energy Policy, 27, pp. 585-601, 1999.

[16] Morris, J., Paltsev, S. \& Reilly, J., Marginal Abatement Costs and Marginal Welfare Costs for Greenhouse Gas Emissions Reduction: Results from the EPPA Model, MIT press: Cambridge, M.A, 2008. 